http://kitaibelia.unideb.hu/

ISSN 2064-4507 (Online) • ISSN 1219-9672 (Print)

(C) Department of Botany, University of Debrecen, Hungary

23 (2): 197-206.; 2018

DOI: $10.17542 /$ kit.23.197

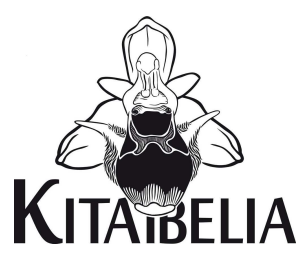

\title{
Adatok Magyarország flórájához és vegetációjához III.
}

\author{
ERDős László1* ${ }^{*}$, ARADI Eszter², BÁTORI Zoltán³ \& TÖLGYESI Csaba ${ }^{3}$ \\ (1) MTA Ökológiai Kutatóközpont, Ökológiai és Botanikai Intézet, H-2163 Vácrátót, Alkotmány utca 2-4.; \\ *erdos.laszlo@okologia.mta.hu \\ (2) Kiskunsági Nemzeti Park Igazgatóság, H-6000 Kecskemét, Liszt Ferenc utca 19. \\ (3) Szegedi Tudományegyetem, Ökológiai Tanszék, H-6726 Szeged, Közép fasor 52.
}

\section{Data to the flora and vegetation of Hungary III.}

\begin{abstract}
We report the occurrence data of 44 vascular plant taxa collected at various localities in Hungary (mainly the Danube-Tisza Interfluve and South Transdanubia) during floristic, vegetation and ecological field surveys between 2016 and 2018. Of the species in the present article, 27 are protected or strictly protected. In the paper we focused on plants that are rare regionally (e.g. Botrychium lunaria, Polystichum aculeatum) or in the whole country (e.g. Ophrys oestrifera, Ranunculus psilostachys), as well as on plants that occurred in unusual habitats (e.g. Corydalis solida). We also included new localities of weedy species, some of which (e.g. Opuntia humifusa, Sporobolus cryptandrus) may present nature conservation threats.
\end{abstract}

Keywords: Danube-Tisza Interfluve, legally protected plants, South Transdanubia

Összefoglalás - Cikkünkben 44 edényes növényfaj új előfordulási adatait közöljük, melyek 2016 és 2018 között végzett florisztikai, vegetációtani és ökológiai kutatásaink során kerültek elő hazánk különböző részeiből (főként a Duna-Tisza köze és a Dél-Dunántúl területéről). A fajok közül 27 védett vagy fokozottan védett. Főként a regionálisan (pl. Botrychium lunaria, Polystichum aculeatum) vagy országosan ritka (pl. Ophrys oestrifera, Ranunculus psilostachys), valamint a szokatlan élőhelyekről előkerült fajokra (pl. Corydalis solida) koncentráltunk. Gyomok új előfordulási adatait is közöljük, melyek közül némelyik természetvédelmi problémát jelenthet a jövőben (pl. Opuntia humifusa, Sporobolus cryptandrus).

Kulcsszavak: Dél-Dunántúl, Duna-Tisza köze, védett növények

\section{Bevezetés}

Korábban megjelent tanulmányainkban (BÁTORI et al. 2014, ARADI et al. 2017) Magyarország különböző tájairól közöltünk új előfordulási adatokat, főként védett, ritka vagy különleges élőhelyen megtalált növényfajokról. Jelen közleményünkben az utóbbi években végzett florisztikai és vegetációtani kutatásaink során előkerült adatokat közöljük, döntően a védett, a lokálisan ritka, vagy szokatlan helyeken felbukkant fajokra koncentrálva.

\section{Anyag és módszer}

Az előfordulási adatokat kistájakhoz (DövÉNYI 2010) és településekhez rendeltük. A dűlők megnevezésekor a turistatérképek (1:40000), az 1:25000 méretarányú katonai, valamint az 1:10000 arányú topográfiai térképek által használt neveket alkalmaztuk. A taxonok sorszámozása és nevezéktana az Új magyar füvészkönyvet (KIRÁLY 2009) követi. Az előfordulási 
helyekhez tartozó CEU-kódok (KIRÁLY \& HORVÁTH 2000) szögletes, az észlelések évei kerek zárójelben szerepelnek.

A florisztikai adatokat egyes esetekben cönológiai felvételekkel egészítjük ki. A felvételek készítése során a jelzett méretű kvadrátban szintenként becsültük a növényfajok borítását a Braun-Blanquet skála szerint. Azokban az esetekben, amikor két aszpektusban is felvételeztünk, a cönológiai felvételben mindig a nagyobb borítási értéket tüntetjük fel. A kistájak megnevezésekor az alábbi rövidítéseket alkalmazzuk:

Duna-Tisza köze

BH: Bugaci-homokhát

CSS: Csepeli-sík

DMH: Dorozsma-Majsai-homokhát

I: $\quad$ Illancs

KH: Kiskunsági-homokhát

KS: Kalocsai-Sárköz

SS: Solti-sík

\section{Dél-Dunántúl}

DB: Dél-Baranyai-dombság
M: Mecsek-hegység
MTS: Mohácsi teraszos sík
V: Villányi-hegység
Dunántúli-középhegység
BUD: Budai-hegyek

\section{Enumeráció}

Duna-Tisza köze

18. Botrychium lunaria (L.) Sw. - BH: Imrehegy: nyáras-borókás szegélyében, cserjék alatt, két példány [9582.1] (2018). Imrehegyről korábban nem közölték (FARKAS 1999, SZERDAHELYI 1999, BARTHA et al. 2015), legközelebb az ásotthalmi Emlékerdőben él (ERDős et al. 2013). KH: Táborfalva: lőtér [8882.3] (2018), nyáras-borókás alatt, egy kb. 150 példányos és egy kb. tíz egyedes populációban. BARTHA et al. (2015) nem jelzi innen, pedig CSÓKA \& VERŐ (2013) közöltek a területről egy kb. 70 egyedből álló populációt, amely a leírás szerint az általunk talált első populációval azonos.

346. Silene dichotoma Ehrh. - SS: Solt: csatornapart ruderális növényzetében, löszös talajon néhány tucat tő [9280.1] (2018). Közvetlen közelében előforduló gyakori fajok: Achillea asplenifolia, Carduus acanthoides, Dactylis glomerata, Elymus repens, Picris hieracioides, Poa angustifolia. BARTHA et al. (2015) alapján az Alföld jelentős részéről hiányzik, a Duna-Tisza közének csak az ÉK-i részéről közöl adatokat, míg a nyugati oldalon egyáltalán nem jelzi. A legközelebbi ismert recens előfordulásai a Mezőföld nyugati oldalán vannak. A 19. századból archív adatai ismertek a Duna-Tisza köze több pontjáról, így pl. Páhiról, Kalocsáról, Pestről, Szakmárról, továbbá az Akasztó és Dunapataj közötti térségből (SzUJKó-LACZA et al. 1993. A 20. század második feléből SzUjKó-LACZA et al. (1993) említi még Bugac és Szank közeléből is, illetve egy mára már akácinvázió miatt megsemmisült állományát említhetjük a kecskeméti Borbáspuszta mellől (Tölgyesi Csaba, saját megf.). Egykor elterjedt szántóföldi gyom volt, mely mára visszaszorult és országos szinten veszélyeztetetté vált (PINKE \& PÁL 2005).

416. Pulsatilla nigricans Störck - I: Kéleshalom: telepített fenyvesben, a településtől kb. 2 km-re keletre, egyetlen tő, további néhány tő nyílt homoki gyepi és fehér nyáras fragmentumokban [9681.2] (2018). A XX. század elején és közepén a szomszédos települések (Császártöltés, Kunfehértó és Jánoshalma) közelében, homoki élőhelyeken találták (SzUjKóLACZA et al. 1993). Cönológiai felvétel a fenyves élőhelyről: lombkoronaszint: Pinus nigra 4; gyepszint: Asclepias syriaca 1, Acinos arvensis +, Arenaria serpyllifolia +, Hieracium auriculoides + , Medicago minima + , Poa angustifolia + , Pulsatilla nigricans + , Taraxacum officinale +. Felvétel készítője: Bátori Zoltán; hely: Kéleshalom; idő: 2018.05.06; mintaterület nagysága: $25 \mathrm{~m}^{2}$. 
418. Clematis integrifolia L. - KS: Dusnok: Lenes-erdő, a Lenes-Karasz vadászterülethez tartozó, nagy kiterjedésű vaddisznóskertben, erdőtömbök közötti földút menti mezsgyén, kb. 25 tő [9679.2] (2017). MENYHÁRT (1877) Kalocsa környékén gyakorinak tartja, konkrét előfordulását Hajós és Dusnok között jelzi. A közelből ismert volt még Sükösd és Nemesnádvar közötti területről (MoESZ in SzujKó-LACZA et al. 1993), Érsekcsanádról (KEvEY \& TóTH 2000), Szedresről (Tóth 2014), Sióagárdról (TóTH 2014) és Bogyiszlóról (KEvEY \& TóTH 2000, TóTH 2014). A terület egy részén rendkívül jó állapotú, elegyes erdő található, számos idős fával (főként Quercus robur, Acer platanoides, A. pseudoplatanus, Pyrus pyraster), sűrü, fajgazdag cserjeszinttel (Acer tatarica, Crataegus monogyna, Frangula alnus, Ligustrum vulgare, Rosa canina, Viburnum opulus, Euonymus europaeus, Cornus sanguinea). A cserjék és fák kivétel nélkül számottevő újulattal rendelkeznek a gyepszintben, ahol jellemzőek a gyöngyvirágos foltok is. Jelen van az Epipactis tallosii, illetve számos, az Alföldön ritka faj is képviselteti magát, mint pl. Sanicula europaea, Physalis alkekengi, Mycelis muralis, Parietaria officinalis, Galium odoratum. Inváziós fajok lényegében nincsenek jelen ezekben a tömbökben.

441. Centaurea calcitrapa L. - KS: Dunapataj: a Szelidi-tó közelében, sekély csatorna partján, ruderális növényzetben, 2 tő [9380.3] (2018). Hazánkban ritka (BARTHA et al. 2015); szerepel a magyarországi edényes flóra veszélyeztetett fajainak listáján (KIRÁLY 2007). VoigT \& SOMAY (2013) a szomszédos Madocsa és Paks települések határából jelzi. MENYHÁRTh (1877) a Duna bal partján elhelyezkedő területekről említi. A közelből (Kalocsa és Kiskőrös) herbáriumi adatai is ismertek (vö: BÁToRI et al. 2014). Előfordulása felhívja a figyelmet a vonalas létesítmények fajmegőrzésben betöltött szerepére is (vö.: BáTORI et al. 2016). Az élőhely gyakoribb növényfajai: Anthemis arvensis, Artemisia vulgaris, Dactylis glomerata, Cynodon dactylon, Linaria vulgaris, Medicago sativa, Rubus caesius, Torilis arvensis, Tripleurospermum perforatum.

856. Robinia pseudoacacia L. - CSS: Kunadacs [8981.4] (2017). Közel négy méteres törzskerületével hazánk egyik legnagyobb akácfája (PóSFAI 2005, dendromania.hu).

876. Oxytropis pilosa (L.) DC. - SS: Szalkszentmárton: a településhez DK-i irányban csatlakozó gyep déli részén, kb. 50 tő [9080.1] (2017). A Duna-Tisza közén igen ritka (BARTHA et al. 2015), a közelben jelenleg Kunbaracs, Tatárszentgyörgy és Tass közeléből ismert (KuN et al. 2016). Ezen kívül csak a XIX. század végéről és a XX. század elejéről származó adatai vannak a környékről (SzUjKó-LACZA et al. 1993). A gyepfolt északi része ezüstfával erősen fertőzött, déli felét évtizedekkel korábban lerakott, napjainkra részben földdel borított építési törmelék, illetve vélhetően illegális bányászat után visszamaradt mély gödrök szabdalják. A gyep a zavarás után nagyrészt regenerálódott, relatíve fajgazdag. A gyep további értékes, az adott kvadrátra nézve új fajai: Ophrys sphegodes, Orchis militaris, Blackstonia acuminata, Viola rupestris, Centaurea scabiosa ssp. sadleriana. Egyéb említésre méltó fajok: Orchis coriophora, Orchis morio.

901.2 Vicia pannonica subsp. striata (M. Bieb.) Nyman - CSS: Kunpeszér [8981.1] (2016), KS: Újtelek [9380.3]. Mindkét területen középkorú parlagokon és mezsgyékben elterjedt, bár nem gyakori. Az adat közlését jelen esetben a régió adathiányos jellege indokolja: BARTHA et al. (2015) a V. pannonica s.l. minimális előfordulását jelzi a Duna-Tisza köze északi és Duna melletti részéből. Cönológiai felvétel a kunpeszéri előfordulásból: Achillea collina 2, Arabis hirsuta +, Arenaria serpyllifolia +, Bromus sterilis + , Cerastium pumilum +, Dactylis glomerata 4, Falcaria vulgaris 1, Festuca pseudovina 1, Myosotis ramosissima +, Phragmites communis + , Picris hieracioides + , Silene alba + , Verbascum phoeniceum 1, Veronica arvensis +, Vicia pannonica subsp. striata 1, Viola arvensis +. Felvétel készítője: Tölgyesi Csaba; hely: Kunpeszér; idő: 2016.05.21.; mintaterület nagysága: 4 m².

984. Dorycnium herbaceum Vill. - KH: Izsák (Kurjantó): kiszáradt, degradált növényzetû útmenti árokban, kb. 20 m-es szakaszon mindkét parton [9182.1] (2018). Az élőhely gya- 
koribb növényfajai: Asclepias syriaca, Calamagrostis epigeios, Dactylis glomerata, Festuca arundinacea, Galium verum, Silene alba, Solidago gigantea, Sonchus arvensis, Torilis arvensis. 1192. Opuntia humifusa (Raf.) Raf. - KH: Kunbaracs [9082.1] (2018). Néhány, virágzó és terméses hajtásokkal rendelkező telep, zavart nyílt homoki gyepben. Észak-Amerikai eredetű, szárazságtűrő faj. Gyakoribb fajok a közvetlen közelben: Artemisia campestris, Asclepias syriaca, Bromus tectorum, Cynodon dactylon, Secale sylvestris, Xeranthemum annuum. BARTHA et al. (2015) nem listázza magyarországi előfordulásait, de KIRÁLY (2009) említést tesz róla, hogy száraz gyepekben kivadulhat, noha helymegjelölést nem ad. Publikált adata ismert a Villányi-hegységből (ERDős et al. 2014), de kiskunsági előfordulásról nem találtunk adatot.

1363. Samolus valerandi L. - CSS: Kunpeszér [8981.1] (2018). Jó állapotú, idős parlagon áthaladó, kiszáradó csatorna medre a Kiskunsági Nemzeti Park Peszéradacsi rétek nevú területén. Az állomány több kisebb foltba tömörül és a csatorna mintegy 150 méteres szakaszán terül el. A csatorna diverz növényzetéből az alábbi fajok emelhetők ki: Bolboschoenus maritimus agg., Carex viridula, Lotus tenuis, Lycopus europaeus, Phragmites australis. Korábban nem volt ismert a védett területről és annak közeléből. Legközelebbi ismert előfordulásai Budapest közelében és Dunapataj mellett a Szelidi-tónál (SzujKó-LACZA et al. 1993, BARTHA et al. 2015), valamint Cegléd mellett a Csíkos-szélen (TAKÁCs et al. 2016) vannak. A dunapataji előfordulását a flóraatlasz archív adatként (1951-1990) említi, de itt is megtaláltuk a tó ÉNy-i partján ritkás nádasban (Agrostis stolonifera, Lycopus europaeus, Phragmites australis, Stachys palustris társaságában).

1784. Cephalaria transsylvanica (L.) Schrad. - BH (KS határán): Kiskőrös: az erdőtelki lápra telepített fásszárú ültetvény (hibrid füzes) szegélyében, az Erdőteleket és a Dunavölgyi főcsatornát összekötő széles földút mentén [9381.3] (2018), elszórtan néhány tucat tő. Legközelebbi ismert állományai BARTHA et al. (2015) szerint a Duna-mentén találhatóak. A közeli Szelidi-tó mellől archív adatait ismerjük (Kitaibel 1800 in Gombocz 1945, MENYHÁRTH 1877).

1941. Tephroseris integrifolia (L.) Holub - BH: Imrehegy: nyáras-borókás szegélyében [9582.1] (2018). A közelben korábban jelezték előfordulását Bugacról (SzODFRIDT 1969), Kunfehértó mellől (Prodan 1915, CsiKY 2005), Jánoshalma mellől (ProdAN 1915), valamint Hajósról (SimONKAI in SZUjKó-LACZA et al. 1993).

1971. Jurinea mollis (L.) Rchb. - KH: Táborfalva: lőtér [8882.3] (2018). Az Alföldön ritka (FARKAS 1999, BARTHA et al. 2015), a közelből ismert adatai: Kerekegyháza (BoROS in SzUjKóLACZA et al. 1993, Szabadszállás (Boros in SzujKó-LACZA et al. 1993), Izsák (KitAibel in GomBocz 1945).

2240. Leucojum aestivum L. - KS: Hajós: a nagy kiterjedésű szántóföldek közé ékelődő Méhes-dűlői csatornák és erek mentén épségben megőrződött keskeny, lápi jellegű (tőzeges, pangóvizes talaj, lápi növényzet) nádas-harmatkásás vonulatok magassásos szegélyében több foltban, minimum 80-100 tő. [9680.1] (2017). A vidéken viszonylag elterjedt (pl. Menyhárt 1877, Boros 1936, SzujKó-Lacza et al. 1993, Kevey \& Tóth 2000). BARTHA et al. (2015) több közeli kvadrátból is jelzi, azonban a jelzett kvadrát új előfordulásnak minősül.

2260. Iris variegata L. - KS: Dunapataj: a Duna-völgyi főcsatorna mellé telepített kb. 10 éves hazai nyaras szegélyében kb. 50 polikormon [9381.3] (2017). A környéken meglehetősen ritka (SZUJKó-LACZA et al. 1993, BARTHA et al. 2015), legközelebbi ismert előfordulásai: Hajós (MENYhárT 1877, FACSAR in SzUjKó-LaCZA et al. 1993), Izsák (Kitaibel in Gombocz 1945), Páhi (KitAiBeL in GomBocz 1945). A közeli árok cserjésedése miatti égetés során 2017-ben az erdő nagyja is leégett, aljnövényzetében gyakori a Brachypodium pinnatum és ebben az évben tömeges volt a Cephalanthera damasonium. 
2289. Luzula campestris (L.) DC. - DMH: Kisszállás: Jánosteleki-erdő, természetközeli fehérnyáras szegélyében [9783.2] (2016). A Duna-Tisza közén szórványos, a közelből korábban nem ismertük előfordulását (vö. SzUjKó-LACZA et al. 1993, BARTHA et al. 2015).

2394. Elymus elongatus (Host) Runemark - KH: Izsák (Kurjantó): ruderális útszéli növényzetben tíz polikormon, valamint csatorna partján egy polikormon [9182.1] (2018). Kunadacs: erősen legeltetett üde homoki gyepben [8981.4] (2018). A kurjantói előfordulás útszéli növényzetében előforduló gyakoribb növényfajok: Apera spica-venti, Artemisia vulgaris, Asclepias syriaca, Cardaria draba, Convolvulus arvensis, Silene alba, Torilis arvensis, Verbena officinalis. BAGI \& SzÉKELY (2006) csupán 4 kvadrátból jelzi, ahol a faj természetközeli gyepekhez kötődik (a tatárszentgyörgyi és a nyárlőrinci állományok az általunk jelzett populációkhoz viszonylag közel, 10-40 km távolságon belül találhatók). Az utóbbi években azonban számos újabb előfordulása lett ismert (TAKÁCS et al. 2014, MolNÁr et al. 2016, KIRÁLY \& KIRÁLY 2018), elsősorban degradált élőhelyekről, pl. útszélekről, került elő. Az általunk talált, útszéli és csatornaparti növényzetben előforduló populációk tovább erősítik azt a nézetet, miszerint a faj potenciális inváziós képessége nem elhanyagolható. Terjedésének elsődleges forrását feltételezhetően az energiafü-ültetvények jelentik (KIRÁLY \& KIRÁLY 2018).

---- Sporobolus cryptandrus (Torr.) A. Gray - BH: Kiskunhalas: telepített fenyvesekkel körülvett kisméretű homoki erdőssztyepp foltban, a településtől kb. 2 km-re északra, kb. 20 m $\times 20$ m-es területen [9582.2] (2018). Magyarországi előfordulása 2016 óta ismert, Debrecenben, majd Kiskunhalas közelében is megtalálták (TöRöк \& ARADI 2017). Ennek az észak-amerikai füfajnak az újabb hazai előfordulása természetvédelmi kérdéseket vet fel, ugyanis terjedésével a sérülékeny nyílt homoki gyepjeinket veszélyeztetheti. Cönológiai felvétel: Alkanna tinctoria + , Arenaria serpyllifolia + , Asclepias syriaca + , Bothriochloa ischaemum 1, Centaurea arenaria + , Cynodon dactylon + , Erophila verna + , Euphorbia seguieriana 1, Festuca vaginata 3, Fumana procumbens 1, Holosteum umbellatum +, Kochia laniflora +, Medicago minima +, Poa bulbosa +, Populus alba 1, Potentilla arenaria 1, Sporobolus cryptandrus 1 , Stipa borysthenica 3, Syrenia cana + , Viola kitaibeliana + . Felvétel készítője: Bátori Zoltán; hely: Kiskunhalas; idő: 2018.05.07; mintaterület nagysága: $25 \mathrm{~m}^{2}$.

2565. Eriophorum angustifolium Honck. - BH: Kiskőrös, a soldvadkert-kaskantyúihármashatár közelében, a Büdös-tói csatorna mentén elterülő gyep délkeleti sarkában [9382.3] (2016). A Duna-Tisza közén igen ritka (SzujKó-LaCZA et al. 1993, BARTHA et al. 2015), korábbi adatai: Bugac (JávorKA in SzujKó-LACZA et al. 1993), Monor (Tuzson 1915), Dabas (TUZSON 1915), Izsák (TölGYESI in SZUjKó-LACZA et al. 1993), Kecel (MENYHÁRT 1877), Ócsa (SZUjKó-LACZA et al. 1993), Orgovány (TöLGYESI in SZUJKó-LACZA et al. 1993) 2016-ban a gyepen U-alakban elterülő mély fekvésű, részben zsombékoló magassásos növényzetben, és annak szegélyében tízezres nagyságrendben virágzott. A későbbiekben a környező kiszáradó kékperjés láprétek, mocsárrétek felmérését is elvégezték a KNPI szakemberei. A terület további védett fajai a Gymnadenia conopsea, Epipactis palustris, Dactylorhiza incarnata, Orchis militaris, Orchis palustris, Iris sibirica, Cirsium brachycephalum, illetve említésre méltó a Gratiola officinalis több ezer töves állománya és a gyapjúsással azonos lelőhelyen megjelenő, szórványosan előforduló Valeriana dioica. BARTHA et al. (2015) alapján az E. palustris és az $O$. palustris kivételével az összes előfordulás a kvadrátra új adat.

2622. Carex humilis Leyss. - DMH: Kisszállás: Jánosteleki-erdő, természetközeli fehérnyárasban [9783.2] (2016). A Duna-Tisza közén szórványos (SzujKó-LACZA et al. 1993), ebből a kvadrátból BARTHA et al. (2015) szerint korábban nem jelezték. Cönológiai felvétel: lombkoronaszint: Populus alba 4; cserjeszint: Crataegus monogyna 3; gyepszint: Achillea pannonica + , Alliaria petiolata + , Asparagus officinalis + , Asperula cynanchica + , Berberis vulgaris + , Bromus sterilis 1, Calamagrostis epigeios 2, Carex humilis 1, Carex liparicarpos 2, Celtis occidentalis + , Chenopodium album + , Conyza canadensis + , Crataegus monogyna + , 
Cynodon dactylon + , Cynoglossum officinale + , Eryngium campestre + , Falcaria vulgaris + , Festuca rupicola + , Galium aparine + , Galium verum + , Gleditisa triacanthos + , Iris arenaria + , Padus serotina + , Phleum phleoides + , Poa angustifolia 1, Populus alba + , Prunus spinosa + , Seseli annuum +, Stellaria media 1, Taraxacum laevigatum agg. +, Tephroseris integrifolia +, Teucrium chamaedrys + , Thymus pannonicus +, Verbascum lychnitis +, Veronica prostrata +, Vincetoxicum hirundinaria +, Viola rupestris +. Felvétel készítői: Erdős László, Tolnay Dolly; hely: Kisszállás, Jánosteleki-erdő; idő: 2016.04.15. és 2016.07.17.; mintaterület nagysága: $25 \mathrm{~m}^{2}$.

2666. Epipactis tallosii A. Molnár et Robatsch - KS: Dusnok: Lenes-erdő, a Lenes-Karasz vadászterülethez tartozó, nagy kiterjedésű vaddisznóskert erdejében [9679.2] (2017). Az ország egész területén ritka faj, a környékről korábban sehonnan nem volt ismert előfordulása (MOLNÁR 2011, BARTHA et al. 2015).

2672. Epipactis atrorubens Hoffm. ex Besser - KH: Táborfalva: lőtér [8882.3] (2018), apró nyáras-borókás erdőfoltban, egyetlen példány. MOLNÁR (2011) és BARTHA et al. (2015) a környékről csak 1950. előtti előfordulásokat jelez, CsiKY (2005) a közeli Nagykőrösről közölte. Cönológiai felvétel: lombbkoronaszint: Padus serotina 1, Populus alba 3; cserjeszint: Crataegus monogyna 4, Ligustrum vulgare 1, Populus alba 2, Prunus spinosa +; gyepszint: Berberis vulgaris + , Carex liparicarpos + , Celtis occidenalis + , Crataegus monogyna + , Epipactis atrorubens + , Ligustrum vulgare 1, Polygonatum odoratum + , Prunus spinosa +, Rhamnus catharticus +. Felvétel készítője: Erdős László; hely: Táborfalva, lőtér; idő: 2018.05.05. és 2018.07.28.; mintaterület nagysága: $25 \mathrm{~m}^{2}$.

2716. Ophrys oestrifera M. Bieb. - CSS: Kunadacs [8981.4] (2016). A 2018-ban közel 550 virágzó példányt számláló állomány 2016-ban került elő, és tekintettel a faj ritkaságára, fontosnak tartottuk a közlést annak ellenére, hogy ebből a kvadrátból már ismert volt a faj. A növény lelőhelye védett területen kívül esik, a szántók által határolt, 14 hektáros, alapvetően szegényes fajkészletű gyepfolton mindössze $\mathrm{kb} .1000 \mathrm{~m}^{2}$-en fordul elő a faj. A szarvasbangóval nagyjából átfedő területen tömeges az Ophrys sphegodes, a gyep egészén gyakori az Orchis coriophora, a mélyebb fekvésű részeken jelen van az Orchis palustris, a Gymnadenia conopsea, egy foltban az Iris spuria.

\section{Dél-Dunántúl}

34. Asplenium javorkeanum Vida - V: Siklós: a posta kőkerítésén, mindössze 4 tő [0175.2] (2017). Nagyharsány: Fekete-hegy, a délnyugati lejtő sziklagyepjében és a nyugati oldal felhagyott kőfejtőjében, néhány tucat példány [0176.1] (2018). A Villányi-hegységben a természetközeli sziklagyepekben fordul elő, de helyenként mesterséges élőhelyeken is megtalálható (CsIKY et al. 2009, ERDős et al. 2011). A Fekete-hegyről korábban egyetlen példány volt ismert, a déli oldalról (BÁTORI et al. 2010). Siklós belterületéről eddig nem jelezték.

51. Polystichum aculeatum (L.) Roth - MTS: Mohács: a kórház belső udvarán, kőfalon, egyetlen példány [0078.1] (2018). Az Alföldön igen ritka (FARKAS 1999), a közelben a Dráva-síkról van néhány adata (CSIKY 2005, BÁTORI et al. 2010, CsiKY et al. 2017). Mohács közeléből nem volt ismert (BARTHA et al. 2015). Hasonló antropogén élőhelyeken alkalmanként felbukkanhat (TAMÁs et al. 2017), a Mohácshoz viszonylag közeli Pécs városában épület homlokzatán és garázsfalak repedéseiben bukkant fel (CsikY et al. 2009).

54. Dryopteris affinis (Lowe) Fraser-Jenk. - M: Orfú: Vásáros-út körüli töbrökben, a nagyobb töbrök alján szórványos [9874.4] (2018). A területről már ismert (BÁTORI et al. 2006, 2010), de az újabb előfordulások megerősítik a korábbi vizsgálatok eredményeit, miszerint a faj kifejezetten jól érzi magát a hűvösebb és párásabb mikroklímájú töbrök alján, többféle 
páfrányfaj (leggyakrabban Athyrium filix-femina és Dryopteris filix-mas) társaságában. Feltételezhetően a területen terjedőben van, ugyanis a korábbi (kb. 10 évvel ezelőtti) terepi kutatások során a 2018-ban előkerült tövek egy részét még nem találtuk. Vélhetően az egész Mecsekben terjedőben van (v.ö. CsiKY et al. 2017). Országosan egyre több előfordulása ismert (BARTHA et al. 2015, CSIKY et al. 2017, KIRÁlY \& KIRÁLY 2018, SCHMIDT et al. 2018, То́тн 2018).

180. Fagopyrum esculentum Moench - V: Villány: szőlőhegy, valószínűleg kivadulás [0176.2] (2016). Korábban a hegység területéről csak Vókányból ismertük (SIMONKAI 1876).

374. Dianthus giganteiformis Borbás - V: Siklós: Göntér, degradált gyepfoltban néhány tucat tő [0175.2] (2017). Virágozni a kaszálás miatt csak a gyepfolt szélén tud. A Villányihegység száraz gyepeiben többfelé megtalálható (DÉNEs 2000, ToLNAY 2016), de a Göntérről korábban nem ismertük.

388. Helleborus odorus Waldst. et Kit. - DB: Kisjakabfalva: Vizes-erdő, néhány tucat példány, Allium ursinum, Anemone ranunculoides és Corydalis cava társaságában [0176.2] (2016). HoRVÁT (1942) szerint a Mecsekalján közönséges. Konkrét előfordulását HoRVÁT (1944) Palkonyáról és Virágosról, BÁTORI et al. (2010) Újpetréről jelzi.

414. Pulsatilla grandis Wender. - V: Csarnóta-Harkány: Nagy-hegy, nyílt sziklagyepben, egyetlen tő [0175.1] (2017). A Villányi-hegységben igen ritka (DÉNES 2000), a Nagy-hegyről korábban nem jelezték (ERDős et al. 2014).

438. Ranunculus psilostachys Griseb. - V: Siklós: Göntér, néhány négyzetméteres állomány degradált gyepfoltban [0175.2] (2017). A Villányi-hegységben elszórtan fordul elő, eddig az alábbi helyekről jelezték: Máriagyűd belterülete és szőlőhegy (BoROs 1944), siklósi Várhegy (BoROS 1944), Szársomlyó (NAGY 1963), Siklós belterülete (VöRöss 1966), Vókány melletti közút szegélye (PRISZTER \& BORHIDI 1967), Tenkes-Csukma tömb (DÉNES 1995, PAPP in DÉNES 1995, KEVEY 2012), villányi szőlőhegy (BÁTORI et al. 2014), villányi Kálvária-domb (ARADI et al. 2017). A Göntérről eddig nem jelezték.

488. Corydalis solida L. - V: Villány: szőlőhegy, irtott bodzás helyén, egyetlen tő [0176.2] (2016). A hegység mezofil erdeiben gyakori, de előfordulása a szőlőhegyen különös, és a mezsgyék természetvédelmi szerepére hívja fel a figyelmet.

636. Sedum spurium M. Bieb. - V: Csarnóta-Harkány: Kis-hegy, felhagyott kőbányában [0175.1] (2016). Korábban nem jelezték a hegységből (HoRVÁt 1942, DÉNES 2000).

1347. Primula vulgaris Huds. - DB: Kisjakabfalva: Vizes-erdő, néhány száz példány [0176.2] (2016). NAGY (1963) Kisjakabfalva erdeiből jelezte, HoRvát (1942) szerint a régió hegy- és dombvidékein közönséges.

1410. Heliotropium europaeum L. - V: Villány, belterület [0176.2] (2017). A Villányihegységben szórványos (ERDős et al. 2010).

1525. Melissa officinalis L. - V: Villány: szőlőhegy, akácos facsoport szegélyében, valószínűleg kivadult [0176.2] (2018). Korábban ismert volt Kistótfalu mellól (HoRvÁt 1957) és a Tenkesről (ERDős et al. 2010).

1768. Lonicera caprifolium L. - DB: Kisjakabfalva: Vizes-erdő, néhány tucat példány [0176.2] (2016). HoRVÁt (1942) a közeli Villánykövesdről és Kistótfaluról jelzi előfordulását. V: Villány: belterület, ültetve [0176.2] (2017). A Villányi-hegységben elterjedt, de dísznövényként ültetett példányait korábban nem jelezték (vö. KEVEY \& BARTHA 2010).

2163. Scilla vindobonensis Speta - DB: Kisjakabfalva: Vizes-erdő, tízezres nagyságrendben [0176.2] (2016). SimonKAI (1876) Villány mellől jelezte közelebbi helymegjelölés nélkül. HORVÁT (1942) nem jelzi Kisjakabfalváról, de NAGY (1963) szerint Kisjakabfalva erdeiben elterjedt.

2170. Muscari botryoides (L.) Mill. - V: Szava: Szavai-hegy [0175.1] (2018). A területről eddig nem jelezték (vö. ERDős et al. 2010). 
2200. Ruscus aculeatus L. - V: Máriagyűd: belterület, ültetve [0175.2] (2016), Siklós: belterület, ültetve [0175.2] (2016). A Villányi-hegység területén elterjedt, elvétve dísznövényként is látható (ERDős et al. 2013).

2241. Galanthus nivalis L. - V: Nagytótfalu: a vókányi vadászháznál egykori gyertyánostölgyes helyén növő akácos-bodzásban, tömegesen [0176.1] (2017). A közelben Kistótfaluról jelezték előfordulását (ERDős et al. 2010). Új adata nem meglepő, mivel a hegység területén gyakori. Villány: belterületen többfelé dísznövényként ültetve [0176.2] (2018).

2704. Orchis purpurea Huds. - V: Máriagyűd: Akasztófa-domb, néhány tő [0175.2] (2017). A hegység területén eddig a Csukma-hegy gerincéről, a Szársomlyóról, a Fekete-hegyről, és a Felső-legelőről volt ismert (ERDős et al. 2011).

2715. Ophrys sphegodes Mill. - V: Máriagyűd: a Márványbánya mögött [0175.2] (2017). A Csukma-dűlőből DÉNEs (1995) közölte előfordulását.

\section{Dunántúli-középhegység}

1915. Tanacetum parthenium (L.) Sch. Bip. - BUD: Budapest: 11. kerület [8580.1] (2018). Járda menti keskeny talajsávokban, ruderális környezetben néhány ponton előfordul. További fajok: Chenopodium album, Poa annua, Taraxacum officinale agg. BARTHA et al. (2015) egy budapesti előfordulását említi, de a pesti oldalról. Az ország egyéb pontjairól is kevesebb, mint egy tucat előfordulása ismert.

\section{Adatközlők}

18: EL; 34: EL, JI; 51: EL; 54: BZ; 131: EL; 180: EL; 346: TCS; 374: EL; 388: EL; 414: JI; 416: BZ, TCS; 418: TÁ, AE, TZ; 438: EL; 441: BZ; 488: EL; 636: EL; 856: EL; 876: AE; 901: TCS; 954: EL; 984: BZ, TCS; 1087: EL; 1192: TCS; 1347: EL; 1363: TCS; 1410: EL; 1768: EL; 1784: AE; 1915: TCS; 1941: EL; 1971: EL; 2163: EL; 2170: EL; 2200: BM, EL; 2240: AE; 2241: EL, JI; 2260: AE; 2289: EL; 2394: BZ, TCS; Sporobolus cryptandrus: BZ; 2565: DCS (kísérő fajok: AE); 2622: EL; 2666: TÁ; 2672: EL; 2704: JI; 2715: JI; 2716: ES

AE: Aradi Eszter, BM: Boros Melinda, BZ: Bátori Zoltán, DCS: Daróczi Csaba, EL: Erdős László, ES: Erdős Sarolta, JI: Jónás István, TÁ: Tamás Ádám, TCS: Tölgyesi Csaba, TZ: Ternyik Zoltán

\section{Köszönetnyilvánítás}

Köszönetünket szeretnénk kifejezni adataik átadásáért Boros Melindának, Daróczi Csabának, Jónás Istvánnak, Ternyik Zoltánnak, valamint a KNPI munkatársainak: Tamás Ádámnak, és Erdős Saroltának. Erdős László kutatásait az OTKA PD 116114 számú pályázat tette lehetővé. Bátori Zoltán Duna-Tisza közi kutatásait a HUSRB/1602/12/0014 és az NKFIH FK 124579 pályázatok, mecseki kutatásait az NKFIH K 124796 kutatási témapályázat támogatta.

\section{Irodalom}

ARAdi E., ERdős L., Cseh V., TöLgyesi Cs. \& BÁtori Z. (2017): Adatok Magyarország flórájához és vegetációjához II. - Kitaibelia 22: 104-113.

BAGI I. \& SZÉKELY Á. (2006): Az Elymus elongatus (Host) Runemark, magas tarackbúza előfordulása a Kiskunság déli részén - a korábbi lelőhelyek rövid áttekintése. - Botanikai Közlemények 93: 77-92. 
Bartha D., Király G., Schmidt D., TiborcZ V., Barina Z., CSiky J., JAKAB G., LeSku B., Schmotzer A., VidéKi R., Vojткó A. \& Zólyomi Sz. (szerk.) (2015): Magyarország edényes növényfajainak elterjedési atlasza. Nyugat-magyarországi Egyetem Kiadó, Sopron, 329 pp.

BÁTORI Z., BARÁTH K. \& CSIKY J. (2006): A Dryopteris affinis (Löwe) Fras.-Jenk. előfordulása a Mecsekben. Flora Pannonica 4: 3-8.

BÁtori Z., KöRmÖczi L., Zalatnai M., ERdős L., Ódor P., Tölgyesi Cs., MARGóczi K., ToRMA A., Gallé R., CsEh V. \& Tӧвӧк P. (2016): River dikes in agricultural landscapes: The importance of secondary habitats in maintaining landscape-scale diversity. - Wetlands 36: 251-264.

BÁtori Z., Bock Cs. \& ERDős L. (2010): Florisztikai adatok a Dél-Dunántúlról. - Kitaibelia 15: 95-100.

BÁtori Z., ERDŐS L., CSEH V., TölgYeSI Cs. \& ARADi E. (2014): Adatok Magyarország flórájához és vegetációjához I. - Kitaibelia 19: 89-104.

Boros Á. (1936): A Duna-Tisza köze kőriserdői és zsombékosai. - Botanikai Közlemények 33: 84-97.

Boros Á. (1944): A Ranunculus psilostachys Griseb. Magyarországon. - Botanikai Közlemények 41: 144-145.

CSIKY J. (2005): Adatok Magyarország flórájához és vegetációjához I. - Kitaibelia 10: 138-153.

Csiky J., Baráth K., Bocz V., Deme J., Fülöp Zs., Kovács D., Nagy K., Tamási B. \& Csikyné Radnai É. (2017): Pótlások Magyarország edényes növényfajainak elterjedési atlaszához V. - Kitaibelia 22: 383-403.

Csiky J., Kovács D., Lengyel A., Pótóné Oláh E., Szabó Zs. \& WirTh T. (2009): Thelypteris palustris Schott és más védett páfrányok előfordulása épületeken, kőfalakon. - Flora Pannonica 7: 57-60.

CsóKA A. \& VERő Gy. (2013): Új kis holdruta (Botrychium lunaria) előfordulás a Kiskunságban. Kitaibelia 18: 183.

DÉNES A. (1995): Adatok a Villányi-hegység flórájához. - A Janus Pannonius Múzeum Évkönyve 40: 5-8.

DÉNES A. (2000): A Villányi-hegység flóra- és vegetációkutatásának története, eredményeinek összefoglalása, különös tekintettel a védett és ritka fajok előfordulására. - Dunántúli Dolgozatok Természettudományi Sorozat 10: 47-77.

DöVÉNYI Z. (szerk.) (2010): Magyarország kistájainak katasztere. - MTA Földrajztudományi Kutatóintézet, Budapest, 876 pp.

ERDŐS L., CSEH V. \& BÁTORI Z. (2013): New localities of protected and rare plants in southern Hungary. Tiscia 39: 17-21.

ERDős L., DÉNES A., KovÁcs Gy., TóTH V. \& PÁL R. (2010): Adatok a Villányi-hegység flórájának ismeretéhez. - Botanikai Közlemények 97: 97-112.

ERdős L., TolnaY D. \& TóTH V. (2011): Kiegészítések a Villányi-hegység flórájához. - Botanikai Közlemények 98: 117-128.

ERdős L., TölgYesi Cs., DÉNes A., DARÁNyi N., Fodor A., BÁToRi Z. \& Tolnay D. (2014): Comparative analysis of the natural and seminatural plant communities of Mt Nagy and other parts of the Villány Mts (south Hungary). - Thaiszia 24: 1-21.

FARKAS S. (szerk.) (1999): Magyarország védett növényei. - Mezőgazda Kiadó, Budapest, 416 pp.

Gomвосz E. (szerk.) (1945): Diaria itinerum Pauli Kitaibelii, I. II. - Magyar Természettudományi Múzeum, Budapest.

HoRVÁt A. O. (1942): A Mecsekhegység és környékének flórája. - A Ciszterci Rend kiadása, Pécs, 160 pp.

HoRvát A. O. (1944): Pótlások a Mecsekhegység és környékének flórájához II. - Botanikai Közlemények 41: 149-151.

Horvát A. O. (1957): Pótadatok a Mecsek hegység és környékének flórájához. - A Janus Pannonius Múzeum Évkönyve 2: 163-180.

Kevey B. (2012): A Villányi-hegység molyhos tölgyesei. - Acta Naturalia Pannonica 4: 35-58.

KEVEY B. \& BARTHA D. (2010): Jerikói lonc (Lonicera caprifolium). - Tilia 15: 112-138.

KeveY B. \& TóTH I. (2002): Adatok a hazai Alsó-Duna-ártér flórájához. - Kitaibelia 5: 131-143.

KIRÁLY G. (szerk.) (2007): Vörös Lista. A magyarországi edényes flóra veszélyeztetett fajai. - Saját kiadás, Sopron, $75 \mathrm{pp}$.

KIRÁLY G. (szerk.) (2009): Új magyar füvészkönyv. - Aggteleki Nemzeti Park Igazgatóság, Jósvafő, 616 pp.

KIRÁlY G. \& KirÁLY A. (2018): Adatok és kiegészítések a magyar flóra ismeretéhez III. - Botanikai Közlemények 105: 27-96.

KIRÁLY G. \& HoRvÁth F. (2000): Magyarország flórájának térképezése: lehetőségek a térképezés hálórendszerének megválasztására. - Kitaibelia 5: 357-368.

Kun R., VAdÁsz Cs., MáTÉ A., KÁlmÁN N., BodoR Á. \& CSATHó A. I. (2016): A borzas csajkavirág (Oxytropis pilosa (L.) DC.) előfordulási adatai és élőhelyei Kunbaracs közelében és a Peszéradacsi-rétek egyéb területein. - Kitaibelia 21: 159-164. 
MENYhÁRTh L. (1877): Kalocsa vidékének növénytenyészete. - Hunyadi Nyomda, Budapest, 198 pp.

Molnár Cs., Lengyel A., Molnár V. A., NAGy T., CsÁBi M., SÜVEges K., Lengyel-Vaskor D., Tóth Gy. \& TaKács A. (2016): Pótlások Magyarország edényes növényfajainak atlaszához II. - Kitaibelia 21: 227-252.

MoLNÁR V. A. (szerk.) (2011): Magyarország orchideáinak atlasza. - Kossuth Kiadó, Budapest, 504 pp.

NAGY I. (1963): Újabb adatok Villány és környéke flórájához. - A Janus Pannonius Múzeum Évkönyve 1963: 75-79.

PinkE Gy. \& PÁL R. (2005): Gyomnövényeink eredete, termóhelye és védelme. - Alexandra Kiadó, Pécs, 232 pp.

Pósfai Gy. (2005): Magyarország legnagyobb fái. - Alexandra Kiadó, Pécs, 167 pp.

PRISZTER Sz. \& BORHIDI A. (1967): A Mecseki flórajárás (Sopianicum) flórájához I. - Botanikai Közlemények 54: 149-164.

PRoDAn Gy. (1915): Bács-Bodrog vármegye flórája. - Magyar Botanikai Lapok 14: 120-269.

Schmidt D., Csiky J. Matus G., Balogh R., Szurdoki E., Höhn M., Ábrán P., Buckó K. \& LőKös L. (2018): Taxonomical and chorological notes 6 (71-74). - Studia Botanica Hungarica 49: 121-130.

SimonKai L. (1876): Adatok Magyarhon edényes növényeihez. - Mathematikai és Természettudományi Közlemények 11: 157-211.

SZERDAHELYI T. (1999): Pteridophyte flora research in the Kiskunság National Park in 1976-80. - In: LőKöS L. \& RAJCzY M. (szerk.), The flora of the Kiskunság National Park II., Magyar Természettudományi Múzeum, Budapest, pp. 415-422.

SzODFRIDT I. (1969): Borókás-nyárasok Bugac környékén. - Botanikai Közlemények 56: 159-165.

SZUjKó-LACZA J., KovÁTS D. \& TöLGYESI I. (1993): Flowering plants in the Kiskunság National Park and the other region between the Danube and Tisza Rivers: Check-list. - In: SzujKó-Lacza J. \& Kováts D. (szerk.), The flora of the Kiskunság National Park I., Magyar Természettudományi Múzeum, Budapest, pp. 66-438.

Takács A., Nagy T., SRamkó G., Lovas-Kiss Á., Süveges K., Lukács B. A., Fekete R., LöKi V., Malatinszky Á., E. Vojtkó A., Koscsó J., Pfliegler W. P., Nótári K. \& Molnár V. A. (2016): Pótlások a Magyarország edényes növényfajainak elterjedési atlaszához I. - Kitaibelia 21: 101-115.

TAKÁcs A., ZÁKÁNy A., Gulyás G., Koscsó J. \& SRAmkó G. (2014): Florisztikai adatok a Tiszántúl északi pereméről. - Kitaibelia 19: 275-294.

TAMÁs J., VIDA G. \& Csontos P. (2017): Contributions to the fern flora of Hungary with special attention to built walls. - Botanikai Közlemények 104: 235-250.

Tolnay D. (2016): A villányi Somsich-hegy természeti értékei, a veszélyeztető tényezők és természetvédelmi teendők. - Kitaibelia 21: 55-62.

TótH I. Zs. (2018): Botanikai adatok Tolnából és Baranyából III. - Kitaibelia 23: 39-50.

TöRÖK P. \& ARADI E. (2017): A new potentially invasive grass, sanddropseed (Sporobolus cryptandrus) discovered in sandy areas of Hungary - A call for information on new localities. - Bulletin of the Eurasian Dry Grassland Group 35: 24-25.

Tuzson J. (1915): A magyar Alföld növényföldrajzi tagolódása. - Mathematikai és Természettudományi Értesítő 33: 143-220.

VoigT W. \& Somay L. (2013): Florisztikai adatok Paks környékéről. - Kitaibelia 18: 35-72.

VöRöSS L. Zs. (1966): A Ranunculus psilostachys Griseb. társulási viszonyai. - Botanikai Közlemények 53: 165-170.

Beérkezett / received: 2018. 09. 06. • Elfogadva / accepted: 2018. 11. 27. 